\title{
Editor's Introduction: Heritage, Preservation, and Decolonization: Entanglements, Consequences, Action?
}

William Carruthers

Until the 1950s, a colossal statue of the pharaoh Ramses II lay on the ground at the archaeological site of Mit Rahina (ancient Memphis), just south of Cairo in Egypt. In January 1955, however, Wing Commander 'Abd al-Latif al-Baghdadi, Egypt's Minister of Municipal and Rural Affairs, visited the site as part of the process of preparing for the statue's removal to central Cairo. ${ }^{1}$ The Wing Commander had been busy overseeing modernization work in the city in the years after Egypt's 1952 Free Officers' coup, an insurrection directed against continued British influence in the country and its unpopularmonarch, King Faruq. Gradually, the coup had turned into a revolution whose figurehead was Gamal Abdel Nasser. And in a plan repurposed from Egypt's colonial era, Ramses was to be a centerpiece of this national recalibration: moved, preserved, and re-erected with great fanfare, his statue would stand in the square by Cairo's main railway terminus (fig. 1). ${ }^{2}$ A permanent fixture outside the bustle of what now became known as Mahattat Ramses (Ramses Station), press stories made certain that the statue became a symbol of Egypt's pharaonic glories remade through the labor of its population. One article even stated that "it should be recalled that the majority of the workmen [restoring the statue] are from the Sa id [Upper Egypt]. They take pride in the work ... because they consider themselves the grandchildren of Ramses II." ${ }^{3}$ As Nasser became a major figure and Egypt became a major player in the era of global decolonization, the Cold War, and non-alignment (not to mention pan-Arabism), Ramses became material-and carefully managed - proof of the florescence of the country's move to independence and its link to the Egyptian masses. Almost overnight, the pharaoh's statue moved from fallen icon to object of revolutionary heritage. Enmeshed within the institutions and networks of post1952 Egypt, Ramses as preserved artifact made revolutionary spectacle material.

Yet fifty-one years later, in 2006, the Egyptian government under the presidency of Husni Mubarak moved Ramses' statue back through Cairo (fig. 2) to a location adjacent to the Great Pyramid, just under twenty miles to the north of Mit Rahina on the Giza plateau. Again with great fanfare, anti-colonial revolution begat neo-liberal - and neo-colonialheritage preservation, an ironic rejoinder to the Nasser era's subversion of a colonial-era project that had aimed to curate the symbolism of the past. Retracing most of his earlier route in reverse, Ramses now became a symbol of another Egyptian regime's ambitions. The statue's new location was the site of the still-to-be-completed Grand Egyptian Museum, whose construction has been funded since 2008 by soft loans funneled through JICA, the Japan International Cooperation Agency. ${ }^{4}$ Moving Ramses to Giza constituted not only a symbol of the Mubarak regime's intentions, but also a signal to donors and debtors that Egypt was a state that would, now and in the future, repay investment. At the time of writing, the

\footnotetext{
${ }^{1}$ Visit noted in Rudolf Anthes' 1955 field diary, January 26, 1955. Mit Rahina records, box 38, folder 10, archives of the University of Pennsylvania Museum of Archaeology and Anthropology. For the movement of the statue and its wider context, see William Carruthers, "Visualizing a Monumental Past: Archeology, Nasser's Egypt, and the Early Cold War,” History of Science 55, no. 3 (2017): 273-301. Cf. Amr Bayoumi (dir.), "Ramses Rah Fayn?" ["Where Did Ramses Go?"], a documentary released at the end of 2019 which relates the story of the statue.

${ }^{2}$ Donald Malcolm Reid, Contesting Antiquity in Egypt: Archaeologies, Museums and the Struggle for Identities from World War I to Nasser (Cairo and New York: The American University in Cairo Press, 2015), 362.

3 “Ramsis al-Thani Yaqifu 'ala Qadamayhi!” [Ramses II Stands on His Feet!'], al-Musawwar, August, 12, 1955.

${ }^{4}$ For this project ("one of the largest museum development projects in the world"), see "JICA-GEM Joint Conservation Project: What is the Grand Egyptian Museum?", accessed July 13, 2020, https://www.jicagem.com/about/what-is-the-grand-egyptian-museum/
} 
regime of the current Egyptian president, 'Abd al-Fattah al-Sisi, desperate to promote economic growth in the country, is pushing hard for the Grand Egyptian Museum's completion. Pictures of the Ramses statue often sit at the center of this work (fig. 3), alongside images of the conservation labs and Egyptian specialists charged with caring for the thousands of objects that form the institution's collection. These days, national spectacle in formerly colonized countries comes pre-loaded with (inter-)national debt. And ironically, that same spectacle allows international donors and experts to claim the ethical upper-hand as calls to decolonize heritage and preservation gain in intensity. Likewise, it allows debtor countries to foreground their own populations as primary agents in the global cultural field at the same time as leaders like al-Sisi strengthen the repressive tools that fortify the power of their states. In the contemporary world order, the economic and social disparities of colonialism have been remade, directed anew. Heritage and preservation, much as they always have been, are part of that revivification.

How and why do such disparities persist? Does the history of "decolonization" itself explain this situation, and does that same history mean that it is difficult for such inequalities ever to be addressed? These questions sit at the heart of this special issue of Future Anterior, which attends to the wider reasons why Mit Rahina's Ramses statue moved from being an object of colonial rule to one of national liberation and, years later, a focus of the international development industry and its asymmetries of power. Ramses II moved from Mit Rahina to Cairo in the midst of a global geopolitical shift to independence that placed Egypt front and center. Yet the connection of heritage-making to the - connected, but discretepolitics and practices of anti-colonialism and decolonization took on a different hue by the time the statue moved from central Cairo to the Giza plateau: an object of national independence became one of national financial obligation, however soft the Japanese loans for the Grand Egyptian Museum, and however impressive the work there made Egypt look. How did such heritage and preservation practices become entangled with the global historical phenomenon of decolonization? What have the afterlives of that entanglement been, and can action be taken to arrest the inequalities in heritage and preservation practice that constitute some of the most obvious consequences of this genealogy? "Decolonization" has never been a neutral word. Can the history of that term ever really be overcome? Can the increasing cooption of the word by the agencies and institutions who direct funding to decolonization initiatives in heritage and preservation ever be reversed?

As I discuss below, historians in the widest sense are only now calling for these questions to be addressed with urgency (certain other scholars and activists are way ahead). In that context, then, this issue makes clear that thinking through the Ramses example and others like it makes possible the broader understanding of the histories at hand - an understanding necessary as global calls for the decolonization of knowledge take on increasing urgency. The Ramses statue, after all, has always been an object of top-down control, buffeted by various political processes: local, regional, and global. It is by attending to examples at the center of such processes that we can come to better know these histories and begin to unravel their consequences; if, that is, they can be unraveled at all.

Put another way, it is imperative - and not at all difficult, despite the objections of various power-brokers - to draw a line between the histories of heritage, preservation, and movements like Rhodes Must Fall, Me Too, Decolonize This Place, and Black Lives Matter, at the same time as it is vital to take seriously the demands that those movements make (and with the humility and empathy to actually listen to the activists directing them). Yet it is also imperative to understand the historical conditions that have made those calls necessary, and the ways in which those circumstances have helped to constitute the heritage and preservation practices under question: not least the way in which institutions in those fields issue calls to "decolonize" themselves. In the case of Ramses, those circumstances might primarily seem 
economic, not least in the form of the loans taken out to build the Grand Egyptian Museum. Given the entangled nature of such domains, though, those conditions have also had a profoundly lived social effect: not only given the impact of debt on the populations of formerly colonized countries like Egypt (where structural adjustment programs have been multiple), but also in terms of who has access to objects of, and expertise in, heritage and preservation, let alone who enjoys authority in speaking about those practices. Historiansas much as preservation specialists themselves - need to understand and help unravel these conditions.

\section{Imperfect Understandings}

Unraveling those conditions means acknowledging exactly how imperfect historical understanding of theinterplay between heritage, preservation, and decolonization is. Heritage and preservation gained increasing prominence as the "second wave" of decolonization took shape (the "first wave," as Mark Thurner argues, had taken place in late eighteenth- and early nineteenth-century South America). ${ }^{5}$ Consequently, that rise in visibility often occurred through the carrying out and publicization of work in newly independent countries: think only of UNESCO's International Campaign to Save the Monuments of Nubia, which took place in Egypt and Sudan from 1960 onward, and whose spectacle was vital to the instantiation of the 1972 World Heritage Convention. ${ }^{6}$ Yet in a recent co-authored article in History Workshop Journal, Elisabeth Leake notes that, despite the growing number of calls for the decolonization of history, "as a scholar whose work is rooted in histories of decolonization ... I am struck by the fact that decolonization as a historical phenomenon is conspicuously absent." Indeed, Leake emphasizes that "there is little discussion or reflection on the processes of empire and its ending, even though these are historical forces that have been absolutely crucial to the world we live in today."7 This special issue seconds that critique. It also contributes to the histories of decolonization in question by reflecting on how such historically grounded work might play a role in addressing the coloniality of knowledge in heritage and preservation today. The question is as much about empire and its end(s) as it is about "empire and its ending": how to address "the continuing hidden process of expropriation, exploitation, pollution, and corruption that underlies the narrative of modernity," as Walter Mignolo and Rolando Vazquez put it. ${ }^{8}$

Scholars in heritage and preservation have started to show an increasing interest in the development of those fields, particularly in the vital inter- and post-war years. Notable recent work in this area includes Lucia Allais' Designs of Destruction: The Making of Monuments in the Twentieth Century, and Lynn Meskell's A Future in Ruins: UNESCO, World Heritage, and the Dream of Peace, alongside other studies that have started to broaden the geographical scope of the histories at hand: Indonesia, Turkey, and Cambodia have all recently been the

\footnotetext{
${ }^{5}$ Mark Thurner, ed., The First Wave of Decolonization (New York: Routledge, 2019).

${ }^{6}$ For the campaign, see Lucia Allais, "The Design of the Nubian Desert: Monuments, Mobility, and the Space of Global Culture," in Governing by Design: Architecture, Economy, and Politics in the Twentieth Century, ed. Aggregate Architectural History Collaborative (Pittsburgh: University of Pittsburgh Press, 2012), 179-215. For an account of how the campaign's forms of knowledge caused social disaggregation from UNESCO's heritage concept, see William Carruthers, "Records of Dispossession: Archival Thinking in UNESCO's Nubian Campaign in Egypt and Sudan,” International Journal of Islamic Architecture 9, no. 2 (2020): 287-314. ${ }^{7}$ Amanda Behm, Christienna Fryar, Emma Hunter, Elisabeth Leake, Su Lin Lewis, Sarah Miller-Davenport, "Decolonizing History: Enquiry and Practice," History Workshop Journal, 170-71.

${ }^{8}$ Walter Mignolo and Rolando Vazquez, 2013, "Decolonial Aesthesis: Colonial Wounds/Decolonial Healings," Social Text Online, accessed July 13, 2020, https://socialtextjournal.org/periscope_article/decolonial-aesthesiscolonial-woundsdecolonial-healings/
} 
focus of substantive work. ${ }^{9}$ More generally, there has been an explosion of scholarship in the histories of archaeology, anthropology, and museums that not only complements these volumes, but also integrates the study of material culture in creative and productive ways. Much of this latter scholarship, however, concentrates on the nineteenth, and first half of the twentieth, centuries, before the entanglement of the end of empire and global preservation efforts took on increased pace. ${ }^{10}$ How did this entanglement happen, what were its results for the ways in which heritage and preservation developed, and what have been the consequences for those fields today? In what ways, too, might these consequences now be grappled with?

As I discuss further below, these questions cannot simply be answered by provenance research, as important as that research can be, and as much as such research seems to have become a major - or perhaps the major - route to provide answers in some places. ${ }^{11}$ The contributors to this special issue therefore address these questions by drawing on a geographically dispersed set of case studies in order to contextualize historically why calls for the decolonization of heritage and preservation have become urgent and widespread. In Egypt, Ramses II became an artifact of a revolution whose spectacle both allowed the often unwelcome expansion of the postcolonial state into people's lives, but which also engendered new and genuine forms of national feeling. ${ }^{12}$ In more recent years, however, his statue has become a symbol of international development's neo-colonial — and neoliberal - integration with heritage work. How did such transformations occur, and how might they be connected to the earlier ways in which decolonization and the making of heritage took place? Emphasizing the global asymmetries to which such transformations are connected, in what ways, if any, have such relationships left room for more positive interventions that enable an escape from, and redrawing of, structural inequalities? Elsewhere, Chiara de Cesari's Heritage and the Cultural Struggle for Palestine has demonstrated the ways in which, despite the globalizing processes it is embedded within, transnational heritage expertise has been appropriated within the areas controlled by the Palestinian Authority after the 1993 Oslo Accords "with anticolonial politics as well as institution building clearly in mind."13 Do — or can —other examples of this redrawing of heritage priorities flourish? Especially as calls for decolonization are mediated and captured by the organizations at which they are directed, this

\footnotetext{
${ }^{9}$ Lucia Allais, Designs of Destruction: The Making of Monuments in the Twentieth Century (Chicago: University of Chicago Press, 2018); Marieke Bloembergen and Martijn Eickhoff, The Politics of Heritage in Indonesia: A Cultural History (Cambridge: Cambridge University Press, 2020); Michael Falser, Angkor Wat: A Transcultural History of Heritage, 2 vols. (Berlin: De Gruyter, 2020); Christina Luke, A Pearl in Peril: Heritage and Diplomacy in Turkey (New York: Oxford University Press, 2019); Lynn Meskell, A Future in Ruins: UNESCO, World Heritage, and the Dream of Peace (New York: Oxford University Press, 2018).

${ }^{10}$ This temporality is of course complex: work in earlier periods self-evidently helped to condition heritage and preservation in the second half of the twentieth century. The following volumes all make this point clear, whether with devoted chapters that do draw them into that period or by emphasizing the colonial afterlives of particular events (especially of the Tutankhamun discovery): Billie Melman, Empires of Antiquities: Modernity and the Rediscovery of the Ancient Near East,1914-1950 (Oxford: Oxford University Press, 2020); Christina Riggs, Photographing Tutankhamun: Archaeology, Ancient Egypt, and the Archive (London: Bloomsbury, 2019); Alice Stevenson, Scattered Finds: Archaeology, Egyptology and Museums (London: UCL Press, 2019).The point, otherwise, is that the archive of "decolonization" (and of heritage, in this case) has not often been imagined-and the conditions for its coming-into-being have often been repressed, for which see e.g. Omnia El Shakry, "'History without Documents': The Vexed Archives of Decolonization in the Middle East," American Historical Review 120, no. 3 (2015): 920-34.

${ }^{11}$ Particularly (in this author's view) in Germany, where the field of Provenienzforschung seems to have taken on heightened importance, not least since the 1998 Washington Principles on Nazi-Confiscated Art.

12 On that feeling (and the "critical consciousness") that accompanied it, see Alia Mossallam, "We Are the Ones Who Made This Dam “High!” A Builders' History of the Aswan High Dam,” Water History 6, no. 4 (2014): 297-314.

${ }^{13}$ Chiara De Cesari, Heritage and the Cultural Struggle for Palestine (Stanford: Stanford University Press, 2019), 26-27.
} 
special issue attends to such concerns, illustrating that knowledge of the practices and forms of power through which this situation has arisen over the longue durée is vital. That knowledge in place, calls for decolonization today can only become more effective.

\section{On Decolonization, Heritage, and Preservation}

To say that "the museum is not neutral" has become almost a truism in the past few years. ${ }^{14}$ When discussing this point and the connected domains of heritage and preservation, however, it is imperative to understand that decolonization has itself never been a neutral process. As Stuart Ward notes, "'decolonization' was made in Europe, as part of a major realignment of metropolitan assumptions and expectations with an ever-encroaching post-imperial world." 15 First used in French in 1836, the term did not enjoy consistent or coherent use until the second half of the twentieth century, when its utility started to become increasingly clear to specific groups of power-brokers. ${ }^{16}$ As Todd Shepard has discussed, even in the 1950s, as the number of newly independent nation-states began to increase, "European and American scholars and politicians hesitantly applied it to describe specific shifts of sovereignty in particular territories." ${ }^{17}$ And that hesitance ultimately points to the word's widespread emergence only in the early 1960s, when the political need for Europeans to "manage" the end of empire became much more urgent.

When decolonization became a widely used word, it became so with a particular, and distinctly European, purpose. As Shepard makes clear, that purpose is one that linked the word to notions of progress heavily embedded in countries like post-revolutionary France. In the early 1960s, during French discussions about how to end the Algerian War of Independence, the term decolonization gained a telos "wholly consistent with a narrative of progress ... [and] the ongoing extension of national self-determination." Or, writ differently, decolonization became "a historical category, an all but inevitable stage in the tide of History." ${ }^{18}$ Consequently, countries (like France) now forcibly engaged in the process could claim that the - conveniently timeless and progressive-gerund of decolonizing continued to constitute expertise and authority safely within Europe and its metropoles. After Algerian independence in 1962, Charles de Gaulle would criticize Britain's incomplete move to decolonize as indicative of a lack of dedication to the development of Europe itself. Implicitly, too, that criticism highlighted the way in which such progress was linked to the continued mobilization of European knowledge practices in formerly colonized nation-states through modernization programs, a situation within which current calls to decolonize find themselves embroiled. ${ }^{19}$

Decolonization had a specific goal. Not everyone, then, felt the need to "decolonize." In Egypt, for instance, the Arabic tahrìr ("liberation") was used to denote the end of colonial

\footnotetext{
${ }^{14}$ For critical and thoughtful discussions on the non-neutrality of the museum and the potential of the co-option of decolonial work by museums, see e.g. La Tanya S. Autry and Mike Murawski, "Museums Are Not Neutral: We Are Stronger Together," Panorama: Journal of the Association of Historians of American Art 5, no. 2 (2019), https://doi.org/10.24926/24716839.2277; John Giblin, Imma Ramos, and Nikki Grout, "Dismantling the Master's House: Thoughts on Representing Empire and Decolonising Museums and Public Spaces in Practice; An Introduction," Third Text 33, nos. 4-5 (2019): Sumaya Kassim, "The Museum Will Not Be Decolonised," Media Diversified November 15, 2017, accessed July 13, 2020, https://mediadiversified.org/2017/11/15/themuseum-will-not-be-decolonised/; Alice Procter, The Whole Picture: The Colonial Story of the Art in Our Museums and Why We Need to Talk About It (London: Cassell, 2020).

${ }^{15}$ Stuart Ward, “The European Provenance of Decolonization,” Past and Present 230 (2016), 231.

${ }^{16}$ Ibid.

${ }^{17}$ Todd Shepard, The Invention of Decolonization: The Algerian War and the Remaking of France (Ithaca, NY: Cornell University Press, 2006), 5.

${ }^{18}$ Ibid., 6.

${ }^{19}$ Ibid., 7.
} 
rule; decolonization itself possesses no Arabic equivalent, even as "colonialism" (al-isti 'mār) does. Cairo's Midan Tahrir - or Liberation Square, which became globally famous during the country's 2011 revolution - had in fact been renamed under Nasser's presidency; it was originally called Midan al-Isma iliyya after the nineteenth-century khedive (or Ottoman viceroy) responsible for its construction. Liberation had constituted the appropriate term as an anti-colonial revolution came into being; and it is that purpose of anti-colonialism that reveals the asymmetries of the term decolonization itself. Indeed, anti-colonial writers like Frantz Fanon found themselves in a position to resist the word's usage: he stated in the first paragraph of his 1961 The Wretched of the Earth that "decolonization is always a violent event." ${ }^{20}$ This history does not render the current use of decolonization in relation to heritage and preservation work null and void. It does, though, render it urgent to understand the historical tensions present in that term, particularly as the violence identified by Fanon was marked, and particularly as those tensions echo a similar genealogy in the heritage-making practices under question. Whether physical, epistemological, material, or psychological, heritage as much as decolonization was always a violent practice.

It is unnecessary to repeat at length that the values imparted through heritage and preservation have long tended toward a Euro-American discourse surrounding "The Modern Cult of Monuments," even as those values became entangled with other positions as European empires began to crumble: anti-colonial, Afro-Asian, pan-Arab, or non-aligned among them. ${ }^{21}$ That situation does, however, prompt an urgent need to understand how the constitution of decolonization as inevitable historical stage overlapped with and strengthened that heritage discourse and its manifestations. As is the case with decolonization more broadly, to constitute this understanding involves moving beyond a methodologically naïve interpretation "of 'diffusion' from European origins." 22 Instead, historical value lies in comprehending how people who found themselves dealing with the imposition and implementation of decolonization worked with it and the experts, practices, and categories that it promoted. By working with that process, they-like Fanon or the Palestinians discussed by de Cesari-helped to establish the meaning and actions that this entanglement developed. Understanding heritage and its relationship with the end of empire, then, involves developing an understanding that does two things: highlights how the power relations connected to that process were always already asymmetrical and built upon a history of European colonial violence and classification (of gender, race, and belief, among other categories); and provincializes narratives that continue to place Europe and Europeans at the center of understanding how that process transpired. The papers in this special issue attend to these two points in various ways.

In her contribution to the issue, Sarah Griswold outlines how the development of aerial surveillance in French-mandate Syria and Lebanon dovetailed with the development of aerial survey and photography as an archaeological tool. Her detailed analysis of such "hightech heritage" in this League of Nations-defined territory makes clear the ways in which the

\footnotetext{
${ }^{20}$ Frantz Fanon, The Wretched of the Earth, trans. Constance Farrington, Penguin Classics edition (London: Penguin, 2001), 1 (and discussed in Ward, "The European Provenance of Decolonization," 254).

${ }^{21}$ On "The Modern Cult of Monuments," see Alois Riegl, "The Modern Cult of Monuments: Its Character and Its Origin," trans. Kurt W. Forster and Diane Ghirardo, Oppositions 25 (1982; originally published in German in 1903): 21-51; cf. Lucia Allais, Designs of Destruction, 16-17. On the development of heritage in western Europe, see Astrid Swenson, The Rise of Heritage: Preserving the Past in France, Germany and England, 1789-1914 (Cambridge: Cambridge University Press, 2013). For the ways in which that development depended upon global contexts, see in particular Astrid Swenson and Peter Mandler, eds., From Plunder to Preservation: Britain and the Heritage of Empire, c. 1800-1940, Proceedings of the British Academy 187 (Oxford: Oxford University Press, 2013) and Paul Betts and Corey Ross, "Modern Historical Preservation-Towards a Historical Perspective," Past and Present supplement 10 (2015): 7-26.

22 Ward, "The European Provenance of Decolonization," 253.
} 
post-war development of archaeology as a science concerned with space had always already been predicated upon a position of spatial — and thus geopolitical-dominance perhaps only possible in what George Stocking once termed "colonial situations." ${ }^{23}$ Discussing the Jesuit priest Antoine Poidebard's sorties with the $39^{\text {th }}$ aviation regiment of the French Levant forces, Griswold emphasizes how "the use of early high-tech heritage techniques in colonial spaces reverberated widely and portended the turn toward technological epistemology that prospered in the decolonizing world," not least because aerial archaeology "was one of several new ways to practice archaeology without having to face the [post-colonial] realities of spade-based archaeology" on the ground.$^{24}$ The violence of military surveillance, it seems, begat the sometime violence of heritage expertise. ${ }^{25}$

Heritage, though, has not always come into being through European intervention, as de Cesari and others have shown. ${ }^{26}$ In her contribution to the issue, Amal Sachedina furthers this conversation by discussing heritage-making practices in the Sultanate of Oman. Since the inception of the Sultanate under Qaboos bin Said in 1970 (with the aid, kept secret for several decades, of British military forces), Sachedina illustrates how the ubiquitous circulation of heritage imagery like the dalla (or traditional coffee pot) has worked to instantiate Oman as "a territorially grounded entity ... tethered to the cultivation of a distinct historical consciousness that is immanent to social relationships, modes of authorizing time, and ethical techniques that permeate modern daily living." 27 Building on this understanding, Sachedina shows in her ethnography how Omani officials (with varying degrees of ferocity) see the deployment of heritage imagery both as a potential means of the country's population coming to terms with globalization and as a way of dealing with the forms of Islamic revivalism promoted by Da'esh (ISIS) and others.

Heritage, or turath - a word which, importantly, carries meanings in Arabic beyond those connected to it in English-matters in Oman, and has long been the object of local attempts to shape its understanding. ${ }^{28}$ In particular, Sachedina shows how government officials have proposed that attachment to certain forms of heritage would enable Omani youth to successfully navigate a future viewed as contingent in a country whose historical Ibadi Islamic tradition had previously allowed a different, more stable (and more hierarchical) conception of time to prevail. Illustrating the performance of such attitudes even when officials engaged in "offering dates and pouring coffee" in government offices, Sachedina emphasizes the role that the governance and administration of heritage has played not only in the making of the independent nation-state, but also the role of heritage-making in overcoming the anxieties of nation-building - for power-brokers and their go-betweens, if not for others. ${ }^{29}$ What, though, of the citizenries who these power-brokers and their institutions claim to represent? That is another question, and one that moves beyond the spatial confines of particular territories.

\footnotetext{
${ }^{23}$ George W Stocking, Colonial Situations: Essays on the Contextualisation of Ethnographic Knowledge (Madison, WI: The University of Wisconsin Press, 1991).

${ }^{24}$ Page ref from Griswold article

${ }^{25}$ On aerial photography and other forms of archaeological overlap with military surveillance technology, see Lynn Meskell, "Imperialism, Internationalism, and Archaeology in the Un/Making of the Middle East," American Anthropologist "early view" version (2020): https://doi.org/10.1111/aman.13413.

${ }^{26}$ De Cesari, Heritage and the Cultural Struggle for Palestine. For further discussion along these lines, see e.g. Nathalie Peutz, Islands of Heritage: Conservation and Transformation in Yemen (Stanford: Stanford University Press, 2018).

${ }^{27}$ Page ref from Sachedina article

28 These other meanings are particularly important in terms of the Arab-Islamic heritage that has been a source of heated discussion since the 1967 naksa (or "setback") of the Arab-Israeli War, for a concise discussion of which see e.g. Nathalie Peutz, "Heritage in (the) Ruins," International Journal of Middle East Studies 49 (2017): 721-28.

${ }^{29}$ Page ref from Sachedina article
} 


\section{On Object Restitution, and Object Agency}

Just as colonialism allowed European countries to attain global geopolitical dominance, so did that subjugation - and decolonization - often remove agency and the ability to represent themselves from the people over whom that dominance weighed. This is hardly an original thought: Edward Said's Orientalism famously set it out over forty years ago. ${ }^{30}$ Yet this line of thinking bears repeating in an age when populism and culture-war seem to be reversing the weight of its credibility. So, too, is that reiteration useful when discussions surrounding particular types of colonially mediated objects have become heavily embroiled in these same arguments.

This is not simply a question related to the place of heritage in formerly colonial qua colonial spaces. Instead, it is a global issue, tied to the transnational movement, channeling, and classifying of people and things that colonialism as a process set in chain, and which coloniality as a set of legacies has perpetuated. Most obviously, discussions surrounding the restitution of objects held by European and North American institutions have become imbricated in this situation, as have arguments connected to the future of monuments commemorating individuals who profited from the construction of racial inequality under the Euro-American aegis. At the time of writing, in Britain, the United States, and elsewhere, the toppling of statues commemorating Confederate generals, slave-traders, and colonial heroes has been allied to Black Lives Matter protests whose most recent direct cause was the murder of George Floyd by the Minneapolis police, but whose historical conditions of being are linked to the imperial project and the global violence of slavery and scientific racism (it would be wrong, as ever, simply to center this movement as emerging from "the West"). Those protests - and those acts of removal - have themselves become embroiled in the culture-war backlash that has followed. Meanwhile, objects held in former colonies have simultaneously become agents of populist and authoritarian political agendas: the statue of Ramses II discussed earlier being a case in point.

Can the coloniality of objects, monuments, and their representation be resolved? Can the practices of heritage and preservation connected to this moment themselves be subverted or otherwise reassembled? The most obvious way in which this situation might be addressed also sometimes seems the most difficult one to achieve. As Sudeshna Guha notes in her contribution to this issue, "the powerful agency of the object world in resisting meaningmaking creates opportunities to devise methods of intervention into [what Laurajane Smith defined as] the authorized heritage discourse." 31 Yet to unleash that agency itself involves having command over the objects necessary to achieve that aim, an outcome that has remained far from simple for many people theoretically in a position to make claims of control upon them. The ability to speak in connection to material culture - not to mention the ability to speak in general-is not one that is willingly granted by certain cultural gatekeepers. As another contributor to this issue (by way of reprint) famously stated, "the subaltern cannot speak." 32 Worse still, "if you are poor, black and female you get it in three ways." 33

In Europe and North America in particular, many institutions seem to be fighting to maintain their stranglehold over objects obtained under colonial rule. In Britain, for example,

\footnotetext{
${ }^{30}$ Edward W. Said, Orientalism: Western Conceptions of the Orient (London: Routledge and Kegan Paul, 1978).

${ }^{31}$ Page ref from Guha article

${ }^{32}$ Gayatri Chakravorty Spivak, “Can the Subaltern Speak?” in Colonial Discourse and Post-Colonial Theory: A Reader, ed. Patrick Williams and Laura Chrisman (Harlow: Pearson Education, 1994), 104.

33 Ibid., 90.
} 
even as university and other, smaller collections have started to accede to dialogue around the repatriation of objects removed under colonialism, national collections seem to be fighting a rear-guard action against just that possibility. ${ }^{34}$ This action has been triggered in part by the November 2018 Rapport sur la restitution du patrimoine culturel africain (Report on the Restitution of African Cultural Heritage) commissioned by French president Emmanuel Macron from philosopher-economist Felwine Sarr and art historian Bénédicte Savoy. Relating specifically to French collections (but having clear implications for institutions in other countries), among other points the report suggested that the standard burden of proof relating to how objects came into collections should be reversed, placing the onus on museums to explain why items had come to be in their possession. ${ }^{35}$

Sarr and Savoy's report constitutes a substantive attempt to reverse the politics of representation analyzed by Said and many others since. More strikingly still, it suggests a recuperative possibility both historically unmatched in the museum world and tempered by a pragmatic rationalism about what is actually achievable. As Sarr and Savoy have highlighted in interviews, their goals with the report have often been overstated or misrepresented entirely: "the point is not to empty museums, which would be an unrealistic goal." 36 As Sarr himself told Deutsche Welle, the presupposition that "the countries making demands want everything back ... does not seem to be the case." $" 37$

Yet such discussions have not stopped museum directors from making statements that are defensive in the extreme. Attracting considerable criticism as a result of his words, Tristram Hunt, Director of London's Victoria and Albert Museum, stated in an opinion piece in The Guardian that "for a museum like the V\&A, to decolonize is to decontextualize: the history of empire is embedded in its meanings and collections, and the question is how that is interpreted." ${ }^{38}$ Elsewhere, too, responses to the Savoy-Sarr report have been lukewarm. The British Museum, long an obvious target of criticism related to repatriation requests, has opened (or continued) discussions on long-term loans and exchange programs with institutions in formerly colonized countries. Simultaneously, the institution has noted the importance of provenance research. It has also, though, stood behind the 1963 British Museum Act, which states that the institution cannot deaccession items from its collections except in a limited number of circumstances. ${ }^{39}$

As the restitution argument continues to simmer, it is unclear how long such defenses will remain tenable. Likewise, it is unclear how long the illusion, particularly beloved of newspaper op-ed pages, that a "debate" about the rights and wrongs of repatriation is possible will last. The British Museum's statement in response to the George Floyd protests drew a

\footnotetext{
${ }^{34}$ University museums attempting to carry out such work include the Pitt Rivers Museum at the University of Oxford, for which see e.g. "Ethnographic Museums and the Shapes of Radical Hope and Reconciliation," accessed July 14, 2020, https://www.prm.ox.ac.uk/ethnographic-museums-and-shapes-radical-hope-andreconciliation

${ }^{35}$ Felwine Sarr and Bénédicte Savoy, Rapport sur la restitution du patrimoine culturel africain. Vers une nouvelle éthique relationelle (Paris, 2018), accessed July 14, 2020, http://restitutionreport2018.com/sarr_savoy_fr.pdf

${ }^{36}$ Kate Brown, “'The Idea Is Not to Empty Museums’: Authors of France’s Blockbuster Restitution Report Say Their Work Has Been Misrepresented," Artnet News, January 24, 2019, accessed July 15, 2020, https://news.artnet.com/art-world/restitution-report-critics-1446934

${ }^{37}$ Ibid., quoting Felwine Sarr in a piece published by Deutsche Welle, accessed July 15, 2020, https://www.dw.com/en/colonial-art-restitution-the-desire-is-not-to-wipe-museums-clean/a-47194605

38 Tristram Hunt, "Should Museums Return Their Colonial Artefacts?", The Guardian, June 29, 2019, accessed July 15, 2020, https://www.theguardian.com/culture/2019/jun/29/should-museums-return-their-colonialartefacts

${ }^{39}$ Mark Wilding, "Museums Grapple with Rise in Pleas for Return of Foreign Treasures," The Guardian, February 18, 2019, accessed July 15, 2020, https:/www.theguardian.com/uk-news/2019/feb/18/uk-museumsface-pressure-to-repatriate-foreign-items
} 
storm of derision, at least on social media. ${ }^{40}$ And it is unclear-especially given the inequalities so clearly visible during the current Covid-19 pandemic - that the flurry of statements released by other cultural and heritage institutions will be taken seriously unless accompanied by positive and proactive action in creating genuine structural change in terms of whose voices get heard within, and amplified by, museums. In a piece published in the aftermath of George Floyd's murder and the accompanying tearing down of Confederate monuments in the United States, Marisa Brown has stated "that preservation [in the country] is facing an existential crisis." That conclusion rings true, not least because, as she discusses, "many of our historic buildings and sites memorialize settler colonialism and white supremacy." 41 So, too, does Brown's prescription for the alleviation of this issue speak sense. Rejecting the "contextualization" of such monuments, Brown suggests:

I want to see preservation organizations and public commissions think critically, and publicly, about how their work has valorized and supported white dominance and supremacy, and what the work and make-up of their organizations would look like if antiracism were mission central. ${ }^{42}$

Brown's are strong - and necessary-words. Yet it is not simply preservation in the United States and Europe where such issues are relevant.

\section{In the "Post-Colony"}

In the formerly colonized world, the reassembly of preservation and heritage practice itself faces difficulties. It is unclear, for example, to what extent the sort of object-agency-as resistance called for by Sudeshna Guha is possible in former colonies, where, over time, nation-making practices have constituted various inequalities among citizenries. Discussing the ways in which the post-independence Indian state made use of antiquities and museum display, in this issue Guha (like Amal Sachedina) emphasizes the ways in which objects and practices connected to preservationist action worked to negate or amplify certain voices even as colonialism drew to a formal end. Importantly, too, Guha makes clear that it was in the very process of colonialism drawing to an end - and in the multiple violences, large and small, that that act and its genealogies entailed - that such inequalities developed.

Decolonization as supposedly progressive act constituted post-colonies ripe for the constitution of heritage hierarchies.

Discussing the partition and creation of independent India and Pakistan, Guha notes that objects belonging to the Archaeological Survey of India were themselves (like the Survey's entire apparatus) partitioned. The consequence of this process includes displays of Harappan jewellery in New Delhi's National Museum which exist in "halved" form, and an "Indian jadeite necklace [that] has an extra pendant since Pakistan received a larger share of the gold jewellery from [the site of] Taxila." ${ }^{\prime 3}$ Partition made objects, while also tying those

\footnotetext{
${ }^{40}$ Alex Greenberger, "Controversy over Museums' Black Lives Matter Statements Continues as Critics Pillory British Institutions," ARTnews June 8, 2020, accessed July 15, 2020, https://www.artnews.com/artnews/news/british-museums-black-lives-matter-statements-controversy-1202690203/. For the British Museum statement, written by the institution's director, see Hartwig Fischer, "A Message from Director Hartwig Fischer," The British Museum Blog, June 5, 2020, accessed July 15, 2020, https://blog.britishmuseum.org/amessage-from-director-hartwig-fischer/

${ }^{41}$ Marisa Brown, "Preservation's Existential Crisis," National Trust for Historic Preservation: Preservation Leadership Forum, June 18, 2020, accessed July 15, 2020, https://forum.savingplaces.org/blogs/marisabrown $1 / 2020 / 06 / 18 /$ preservations-existential-crisis?utm_medium=referral\&utm_source=general ${ }^{42}$ Ibid.

${ }^{43}$ Page ref from Guha article
} 
objects to notions of the nation-state's proper community. Initially, that community was one of "secular nationhood." "44 As Guha discusses, however, object labels in the National Museum's Harappan Gallery currently "embody the exhibits as representatives of Hinduism," despite the questionable basis of that interpretation. ${ }^{45}$ Meanwhile, elsewhere in India the new Bihar Museum's displays of "tribal art" have been mounted without consultation with the communities whom those displays supposedly represent. ${ }^{46}$ Objects are mutable, but that mutability can be directed in ways that make resistance to the inequalities of nation-making practices less likely.

India, of course, does not stand alone in this situation. Returning to the Ramses II statue discussed at the start of this piece as one of many possible examples, the manipulation of objects in the name of preservation and nation has worked to exclude significant numbers of people from accessing forms of heritage in other former colonies, too. Despite (or, more accurately, because of) the popular spectacle of the statue's movement, Ramses was never of the people. Discussing the Grand Egyptian Museum that now constitutes the statue's home, Mohamed Elshahed has noted elsewhere how locating the institution and its collections "in a desert location outside Cairo's city center serves Egypt's current [national] priorities of security and tourist exclusivity." ${ }^{47}$ Expanding upon this point, he reminds us that the museum is located in an area "currently surrounded by unplanned or poorly planned residential areas, with no civic center to speak of." Coupled with "Cairo's current insufficient public transit system ... Egyptians [given the way in which Egyptology's colonial practices separated past from present] will be further alienated from their own ancient heritage." ${ }^{48}$ The architecture of heritage in the post-colony can be used as an act of division: a means of enforcing power relations whose genealogy in colonial knowledge formations - and in the perpetuation of elite interests-is all too clear.

Are there productive ways to attend to such situations and to attempt to dispel their inequities? The reflections in this issue by Vikramaditya Prakash on a 1995 keynote given by Gayatri Chakravorty Spivak at the government city of Chandigarh, India, are pertinent here. Spivak gave her keynote ("City, Country, Agency") at a conference-Theatres of Decolonization: [Architecture] Agency [Urbanism] —of which Prakash was one of the organizers. In a location which itself was formative to Prakash (his father had worked with Le Corbusier on the design of Chandigarh), so that keynote, too, became "formative in my biography." And it is at this reflective biographical juncture that his reflections gain their urgency: Prakash noting that "elite architects [working, he implies, at places like Chandigarh, but also in contemporary, hyper-globalized India] performing easy culturalist readings claiming to speak for 'India' ... have to make sure that these are not just self-serving claims." 49 In her keynote, Spivak had herself suggested that "civic agency is where the hyphen between nation and state wants to tremble into an equal sign." 50 The question for Prakash - and Mohamed Elshahed implies a similar problematic - has been how that trembling might take concrete shape. How might such constructive critique happen?

To be clear, Prakash's reflections draw on what has become a historic document. Yet one reason to re-print Spivak's keynote here is how immediate her concerns at the conference still seem, to the extent that the world is now living their consequences in an accelerated way.

\footnotetext{
${ }^{44}$ Page ref from Guha article

${ }^{45}$ Page ref from Guha article

${ }^{46}$ Page ref from Guha article

${ }^{47}$ Mohammed Elshahed, "The Old and New Egyptian Museums: Between Imperialists, Nationalists, and

Tourists," in Histories of Egyptology: Interdisciplinary Measures, ed. by William Carruthers (New York and

Abingdon: Routledge, 2015): 263.

${ }^{48}$ Ibid., 264.

${ }^{49}$ Page ref from Prakash article

${ }^{50}$ Page ref from Spivak article
} 
Speaking at a moment when "economic restructuring in the post-Soviet world recodes the old scene of decolonization, ${ }^{51}$ " Spivak notes that "the real discourse of postcoloniality ... [sits in] the abundant reports issued by the World Bank." 52 It is not much of a jump from that realization to the Grand Egyptian Museum and the forms of international development finance that make that institution and others like it possible, in addition to the moralizing justifications that move such money around the globe. Nor is there much of a leap from that monumental construction project — which, above all, recodes Egyptian authenticity somewhere between the ancient and a hyper-globalized present - and "a superficial smattering of Sanskrit" being used in attempts to show that "Hindu India is a living heritage as ancient as it is modern." 53 Spivak's concerns are contemporary because the world is grappling with their contrails. It is because the world is in - and shaped by - those conditions, though, that her words now seem especially powerful. Spivak's discussion of failed, postindependence "stagings of decolonization" in India seems about right given the ways in which those stagings have themselves come to seem inescapable elsewhere. ${ }^{54}$ At the same time, though, she also asks the question "do I see any alternatives?" 55 Thinking through that question is where Prakash's contribution to this issue sits.

For Prakash, Spivak's provocation is a call to an architectural and preservationist ethics couched within an "intersubjective" understanding of the social: a "recognition that my actions as an architect are woven into a larger textile that is larger than, exceeds behind and in front, and is larger than the experience of ourselves." of lines from certain Sanskrit texts), to make this recognition is to place the architect's subjectivity and agency within "the holding dhäranā of life, entangled simultaneously with careful consideration of the situational imperative and open acceptance ... of error." ${ }^{.57}$ As a "citizen ... tuned to the subaltern" (but not appropriative of subaltern spatial and design practices), it is such an act that might ultimately "deconstruct the hegemonic verifying fictions of architecture and the architect-hero." ${ }^{58}$ Moreover, it is this move against the verifying fictions of (heritage and preservationist) architecture that seems most apposite in relation to the cases discussed above. Much like Sudeshna Guha's suggestion that "the powerful agency of the object world in resisting meaning-making creates opportunities," however, that move and the recuperative practices it might allow is only possible when conditions authorize it: when Prakash's "open acceptance" becomes possible. Such acceptance can be hard to come by, whether in India or elsewhere.

\section{(Im)possible Utopias? On Recuperative, Decolonial Action}

Recuperative action in heritage and preservation has not come easily, nor have the conditions for taking that action been made easily available. Institutional inertia, for one, has worked to compromise attempts to carry out such work: even in cases where the impetus for recuperative action seems strong. Beyond the legal strategies used by institutions like the British Museum, as decolonial action has risen up the agenda, so attempts to address activist demands have been subject to institutional drift and delay.

\footnotetext{
${ }^{51}$ Page ref from Spivak article

${ }^{52}$ Page ref from Spivak article

${ }^{53}$ Page ref from Spivak article

${ }^{54}$ Page ref from Spivak article

${ }^{55}$ Page ref from Spivak article

${ }^{56}$ Page ref from Prakash article

${ }^{57}$ Page ref from Prakash article

${ }^{58}$ Page ref from Prakash article
} 
A recent case involving Jesus College, University of Cambridge, illustrates this inertia. There, attempts to deal with the history of an object that had long stood on display in the college's dining hall were compromised by institutional politics. The object-a statue of a cockerel known as Okukor - was one of the bronzes taken from the Kingdom of Benin during the notorious British military expedition of 1897. Jesus College students voted to return the bronze in $2016 .{ }^{59}$ In an apparent moment of positive action, the college then proposed to move Okukor to the university's Museum of Archaeology and Anthropology, which was known for being "well-rehearsed in engaging in dialogue with its own complex colonial history," and which might act as "a safe space in which the college's [stated] commitment to 'discuss and determine' Okukor's future could be met." As Johanna Zetterstrom-Sharp and Chris Wingfield have shown, however, that move constituted one that demonstrates "how a stated commitment to postcolonial dialogue can work to circumvent a call for postcolonial action." ${ }^{60}$ Institutional politics within the university (of which colleges are self-governing members) meant that the museum "was ultimately not given the power to enable a conversation" around whether the decision of the student vote should be adhered to. ${ }^{61}$ Consequently, Okukor was quietly returned to Jesus College. It was only in 2019 that direct institutional changes - not least the appointment of Sonita Alleyne as the college's Master, the first woman and person of color to occupy the position-meant that the College Council decided that Okukor should in fact be returned to the Court of Benin in contemporary Nigeria. ${ }^{62}$

Inertia and disingenuity have long hampered calls for restitution. And as ZetterstromSharp and Wingfield observe, in relation to anthropological museums this situation has come into being not least because of its "reliance upon models of archival excavation." ${ }^{\circ 3}$ This analysis might well be directed toward other types of institution, too. Earlier in this introduction, I noted the profusion of provenance research that has arisen as a response to calls for decolonization and object restitution in collections across the spectrum. Yet it is clear that this research is almost always reactive, in addition to being regularly predetermined in its conclusions: the conditions have been created in which "difficult" histories can be displayed, but not necessarily acted upon. Consequently, this is not work that listens to, reflects on, or is genuinely led by calls for restitution and reparative justice: the sort of work demanded both by the case of Okukor and the Sarr-Savoy report. As Zetterstrom-Sharp and Wingfield again note,

by centering the broader ethical possibilities afforded by collections through scholarly [archival] research, the positions adopted by museum directors have deflected specific calls for action by embedding them in a wider framework that simultaneously acknowledges a history of colonial violence while avoiding an obligation to engage in reparative repatriation. ${ }^{64}$

In this context, can the archive ever be put to a more positive, proactive use in terms of thinking through the issues at hand? More broadly, is decolonial action in relation to heritage and preservation actually possible? In the contemporary moment, the fields and

\footnotetext{
${ }^{59}$ Johanna Zetterstrom-Sharp and Chris Wingfield, “A 'Safe Space' to Debate Colonial Legacy? The University of Cambridge Museum of Archaeology and Anthropology and the Campaign to Return a Looted Benin Altarpiece to Nigeria," Museum Worlds: Advances in Research 7, no. 1 (2019): 1.

${ }^{60}$ Ibid., 2.

${ }^{61}$ Ibid., 16.

${ }^{62}$ Ibid., 18.

${ }^{63}$ Ibid., 17.

${ }^{64}$ Ibid.
} 
institutions under discussion often seem to cleave to vague and utopian statements about what, exactly, they can achieve - and at a global level. UNESCO's communications, for instance, regularly constitute a masterpiece of this art: attempting to communicate with "the world" that forms the organization's object, the consequence often seems to be press campaigns that communicate with nobody at all. ${ }^{65}$ Perhaps other utopian practices, however, present some cause for hope. Ferdinand de Jong has noted how artists and activists have intervened in colonial archives as a way of constructing "utopian pasts and futures" from the material found within them. ${ }^{66}$ As De Jong states, "whichever imperial legacies they have found, they have appropriated them for re-significations unanticipated by the colonial masters." ${ }^{67}$ The constitution of new archives constitutes new possibilities for decolonial action. Yet as Zetterstrom-Sharp and Wingfield emphasized, it is also clear that for such action to take place, those archives need to be reworked in a way that allows control over such institutions to be dispersed: allowing them to become part of the sort of "larger [intersubjective] textile" that Vikramaditya Prakash discusses, and opening those archives to activist responses in ways that have otherwise been obstructed. ${ }^{68}$

Other architects have also sought to demonstrate that, if used appropriately, the tools of their discipline can work to provide reparative justice: "re-use as reparation," as Emilio Distretti and Alessandro Petti put it in their contribution to this issue discussing the remnants of fascist architecture in Italy, Ethiopia, and Eritrea. ${ }^{69}$ Again, the basis of this understanding is the sort of inter-subjectivity that actions surrounding Okukor (for example) did not take sufficient account of. Most pointedly, Distretti and Petti discuss workshops, run in collaboration with the Addis Ababa-based architect Rahel Shawl and members of her studio, that called into question the use of the term "decolonization" in the Ethiopian context. Regarding such disagreements, the two authors propose a practice based "on a politics of reciprocity, alliances and a critical understanding of common colonial heritage as a site of conflict and contestation." ${ }^{, 70}$ For Distretti and Petti, this proposal allows a decolonial approach of preservationist "de-modernization" that challenges the very values and power structures that helped bring the architecture at hand into existence and enables the building of new values around it. ${ }^{71}$

The question (for this author, anyway) is whether or not such approaches constitute too little, too late. Similarly, there is the issue of whether criticisms develop around the international funding that often powers such initiatives, in addition to the politics of representation that this financial distribution might imply. Distretti and Petti's work, supported by the Royal Institute of Art in Stockholm, is a genuine attempt to effect change. Think back, though, to the Grand Egyptian Museum: there, funding from JICA might be argued to have had the opposite effect, despite the spectacle - and the real labor and expertise - of Egyptian conservators and curators employed there. Can this circle of despondence ever be overcome? As statues begin to rain down on the earth - and as activists and protesters take it into their own hands to remove objects from institutions like the Musée du Quai Branly in Paris - it is more than clear that global structural change around heritage

\footnotetext{
${ }^{65}$ I am thinking here of the organization's recent "Unite4Heritage" campaign, whose bathetic nature echoes the sort of banality discussed by Allais, Designs of Destruction, 6-7 in relation to post-war monument preservation. For the campaign itself, see UNESCO, “\#Unite4heritage," accessed July 15, 2020,

https://www.unite4heritage.org/

${ }^{66}$ Ferdinand de Jong, "At Work in the Archive: Introduction to Special Issue," World Art 6, no. 1 (2016): 7.

${ }^{67}$ Ibid.

${ }^{68}$ Page refs from Prakash article; Zetterstrom-Sharp and Wingfield, "A 'Safe Space' to Debate Colonial Legacy?"

${ }^{69}$ Page ref from Distretti and Petti article

${ }^{70}$ Page ref from Distretti and Petti article

${ }^{71}$ Page ref from Distretti and Petti article
} 
and preservation is not only overdue, but also taking place in the face of the institutions that would often seek to obstruct it. ${ }^{72}$ The fact remains, though, that institutions in heritage and preservation will either heed this change or attempt to delay or co-opt it. It is likely in the gaps formed in that process that the possibility of making any real alteration to the global status quo will happen.

\section{Conclusion: Critical Intimacy}

Decolonization was never, and has never been, neutral, and neither has the term's connection to heritage and preservation enjoyed a value-free existence. That situation leaves those fields in a difficult place: sutured to their pasts, and mostly unable to propose futures that are all that different. Yet this impasse perhaps also offers a possibility. To return to her re-printed keynote, Spivak discusses how "deconstruction depends on critical intimacy rather than critical distance." It is in that intimate space that laborers in the fields of heritage and preservation dwell. Those workers, as Spivak notes, need to be "morally responsible" for the positions that they hold and the labor that they perform, and it is in their intimacy with that work that such responsibility can emerge ${ }^{73}$ Between the (unlikely) change in conditions that many relevant institutions might effect or in the - much more likely - attempts to delay or coopt change that they will, I think, now enter into, there exists an intimate space within which such moral responsibility can take hold. Anchored to their pasts, there nonetheless exists within these institutions and their staffs the knowledge of their working practices and histories that potentially allows some form of amendment to occur.

I am not, then, arguing for change that pushes responsibility onto people who have supposedly been "decolonized." What I am arguing for is to push the moral onus onto the people who work within the institutions of heritage and preservation now, and who have access to the levers, even the minor ones, that will enable change to occur. Nothing can happen unless those people make a move. As Sumaya Kassim writes in relation to her own experiences with staff at the Birmingham Museum and Art Gallery, making that move means "acceding privilege, and that is almost always painful.,"74 The pain of the privileged, though, is nothing in comparison to the pain of those who have felt the violence that such institutions have continuously had a hand in; bearing in mind, too, that there are already many layers of hierarchy within these places. Critical intimacy for some will mean feeling that pain intimately, moving beyond it - and accepting that they should not be the center of attention (the same, of course, goes for the current author). It is only then that Prakash's "open acceptance" will become possible; if, for some people, it is possible at all.

Likewise, to accede privilege also means questioning the value(s) of the institution itself, and even its very relevance. As I write this conclusion, ICOM, the International Council of Museums, has once again exploded in controversy over the very definition of the institution that is its object. At least part of that controversy relates to a suggested new definition for museums that has been described, despite several years of discussion, as "too political." 75 Despite "the museum is not neutral" becoming a truism, it seems that the institution is still only allowed to become political in a certain set of circumstances (and to the benefit of certain groups of people). Symptomatic of the sort of existential crisis

\footnotetext{
${ }^{72}$ Kate Brown, "Five Activists Were Arrested After Trying to Seize a $19^{\text {th }}$-Century Artifact from Paris's Quai Branly Museum and Return It to Africa," Artnet News, June 15, 2020, accessed July 15, 2020, https://news.artnet.com/art-world/quai-branly-african-artifact-activists-1886920

${ }^{73}$ Page ref from Spivak article

${ }^{74}$ Kassim, "The Museum Will Not Be Decolonised."

75 Jonathan Knott, "Icom in Turmoil after Resignations," Museums Journal, July 17, 2020, accessed July 24, 2020, https://www.museumsassociation.org/museums-journal/news/icom-museum-definition-row-rumbles-on
} 
discussed by Marisa Brown, the controversy in this case might still become generative of a different set of futures, situated with respect to a different set of priorities. Yet it is not at all clear that it will, and that the intimacy with the institution necessary to admit that its issues even exist will be utilized in a productive way. The same is true, and multiplied in scale, across global heritage and preservation more generally. Change can come if gatekeepers in particular act. Yet to conclude slightly pessimistically, that action mostly remains to be seen. Rhodes Must Fall, but Ramses Might Not.

\section{Acknowledgements}

This special issue is based partially on a conference ("Heritage, Decolonisation and the Field: A Conference") held on 26-27 January 2018 and sponsored by the German Historical Institute London, the Max Weber Stiftung, and the AHRC Heritage Priority Area. My thanks go to my co-organizers Indra Sengupta, Andreas Gestrich, and Rodney Harrison, and also to the staff and students who helped coordinate the event. I have written this introduction while a Leverhulme Trust Early Career Fellow in the Department of Art History and World Art Studies at the University of East Anglia, and thank the trust and the department for their support. I also owe thanks to several other people in particular: Jorge Otero-Pailos (for lending this issue space in Future Anterior and for his powers of persuasion); Scott Goodwin (for his excellent editorial work and for going above and beyond when unexpected complications occurred); Ola Seif (for her help finding images); and, last but not least, to all the contributors whose work appears in the following pages. 